Pamiętnik Literacki 2019, 4, s. 173-180

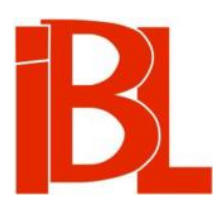

\title{
Co z Murzynkiem Bambo?
}

Rec.: Tomasz Żukowski, Wielki retusz. Jak zapomnieliśmy, że Polacy zabijali Żydów. Warszawa (2018).

Marcin Kula 
Pamiętnik Literacki CX, 2019, z. 4, PL ISSN 0031-0514

DOI: $10.18318 / \mathrm{pl} .2019 .4 .12$

MARCIN KULA Akademia Teatralna im. Aleksandra Zelwerowicza, Warszawa

\section{CO Z MURZYNKIEM BAMBO?}

Tomasz Żukowski, WIELKI RETUSZ. JAK ZAPOMNIELIŚMY, ŻE POLACY ZABIJALI ŻYDÓW. Warszawa (2018). „Wielka Litera”, ss. 430.

Już dawno przeczytana książka nie wzbudziła moich tak sprzecznych uczuć jak ostatnia praca Tomasza Żukowskiego. To nie eufemizm, to prawda. W trakcie lektury rósł mój podziw dla umiejętności zawodowych autora. Chciałbym tak znać literaturę i filmy z zakresu tematu, który również mnie interesuje - i tak móc ją i je analizować. Szanuję, nawet podziwiam Kolegę za odwagę. Wprawdzie jeszcze w Polsce na ogół nie biją, ale po nowelizacji ustawy o IPN można oberwać w inny sposób. Prawda, że z przewidzianych sankcji karnych wycofano się pod naciskiem międzynarodowym, ale coś się pewno znajdzie jako kara za „obrazę narodu”. „Patriotyczna" prasa też zajmie stanowisko. Przy całym podziwie lektura mnie jednocześnie zdenerwowała. Dlaczego? Spróbuję wyjaśnić. Ponieważ główne zarzuty będą dotyczyć skoncentrowania się autora na jednym aspekcie sprawy, z góry deklaruję, że wiem, iż żadna książka nie może traktować o wszystkim.

Zgodnie $\mathrm{z}$ tytułem autor przedstawia, jak twórcy, traktujący o losie Żydów na ziemiach polskich podczas wojny, usiłowali zepchnąc negatywne zachowania polskich chrześcijan na jednostki, zdjąć zaś winę z narodu - wbrew rzeczywistości. Taki przedmiot rozważań ma dwie warstwy: realia oraz dzieje pamięci o nich. Obydwie sa obecne w książce. Ta pierwsza pokazuje sytuację fatalną. Żukowski nie prowadzi własnych badań na ten temat, raczej podejmuje rezultaty działań historyków. Zostawmy na boku dyskusje, jakie się toczą wokół owej sprawy. Niestety, wiele $\mathrm{z}$ nich jest prowadzonych $\mathrm{w}$ stylu zaprezentowanym „w okopach” paryskiego audytorium w lutym 2019. Tymczasem badania prof. Barbary Engelking i prof. Jana Grabowskiego oraz ich zespołu były (i sa) bardzo poważne zawodowo. Ani wymienionych kolegów, ani prof. Jana Tomasza Grossa nie da się zakwalifikować jako „publicystów historycznych”, co ich oponenci nieraz czynią. Pojawiające się w przestrzeni publicznej twierdzenie, jakoby dokonywali oni manipulacji na źródłach w podstawowym dziele stanowiącym efekt pracy kierowanego przez nich zespołu, Dalej jest noc, samo jest manipulacją. Te badania zmieniają funkcjonujący obraz okupacji w rozważanym zakresie. Wypadki zbrodni popełnionych na Żydach przez polskich chrześcijan okazują się znacznie częstsze, niż choćby sam domniemywałem jeszcze niedawno. Prawda, widzę pewne okoliczności, o których warto pamiętać przy czytaniu o nich - nie dla usprawiedliwiania, ale dla pełniejszego obrazu. Myślę o mentalności przedwojennej polskiej wsi. Tak, sam miałem znajomych, którzy 
przechowali się właśnie na wsi. Znane mi są sytuacje ratowania Żydów przez Bataliony Chłopskie. Pamiętam deklarację prof. Heleny Brodowskiej, która współorganizowała te działania: „Stwierdzam z pełną odpowiedzialnością, że wszystkie te świadczenia podejmowano bezinteresownie. Nie znam przypadku stosowania wy-

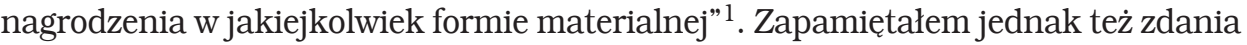
prof. Antoniego Sułka, który zajmował się pewną wsią na Lubelszczyźnie:

Wobec Żydów więcej było wolno także przed wojną. A „za okupacji Niemca” napad na Żyda był zwykle czynem bandyckim, rabunkowym. Żyda łatwo było zabić, nikt go nie obronił, nie szukał i nie pomścił. Słychać to nawet w języku: „zabić Żyda” to nie było to samo co „zabić człowieka”. Na jednego z żydobójców ludzie ze wsi wprawdzie „mścili” (pomstowali), ale nie ciągnęło się za nim piętno mordercy².

I drugie: „Męczeństwo Żydów było dla chłopów czymś widocznym i bolesnym, ale jednak odległym. To nie była "ich sprawa"”3.

Przy interpretacji badań nad losami Żydów, uciekających przed śmiercią, sporo myślałbym właśnie o dystansie między społecznością chrześcijańską a żydowską, jaki istniał w przedwojennej Polsce zarówno na wsi, jak w mieście. Prawda, że bardziej tłumaczy on brak okazywania pomocy niż działania agresywne. Zadawałbym jednak pytanie, dlaczego był on tak duży i okazał się tak trwały. Ten dystans był jaskrawo widoczny podczas okupacji. Jedna z ocalałych, ukrywających się poza gettem, w swoich wspomnieniach opowiada, jak to, jadąc pociagiem, stała się świadkiem złapania innej Żydówki (akurat jeszcze nie jej). Zrobił na niej wrażenie fakt, że pozostali pasażerowie nie tylko nie jęknęli, ale komentowali wydarzenie inaczej, niż gdyby asystowali zabraniu kogoś z Polaków. Prawdę mówiąc, komentowali wręcz okropnie („Wśród tych wypowiedzi nie usłyszałam ani jednego głosu współczucia dla młodej, ładnej kobiety, która w ich obecności została skazana na śmierć” ${ }^{4}$ ). Autorka innych pamiętników, łączniczka ŻOB, zapisała:

Nigdy nie odpłacimy największą nawet miłością i szacunkiem Marysi Sawickiej, która ukrywała w mieszkaniu dwóch ocalonych członków sztabu ŻOB. Została naszym najbliższym przyjacielem. Nie zapomnimy jej nieżyjącej już siostry Anny Wąchalskiej. Nie zapomnimy nieżyjącego adwokata Henryka Wolińskiego, „Wacława”, przedstawiciela Delegatury Rządu, kierownika Referatu Żydowskiego, i nie odpłacimy już wdzięcznością za jego troskę i wielką przyjaźń, ani profesor Prokopowicz-Wierzbowskiej za pomoc w ratowaniu dzieci, profesorowi Kacprzakowi - za ratowanie naukowców, i wielu, wielu innym. Wielu ich było. Wielu zginęło i chyba każdy uratowany ma kogoś, kogo wspomina z szacunkiem i miłością. Ale ulica miała twarz okrutną. Obca. Obojętną, a nierzadko złośliwie uśmiechniętą ${ }^{5}$.

Myśląc o rozważanych kwestiach, brałbym pod uwagę zjawiska, które rozgrywały się wówczas w wielu krajach Europy Wschodniej. Nie tylko zresztą w nich. We Francji, gdzie Żydzi byli w dużo większym stopniu zintegrowani $z$ miejscową ludnością, gdzie modernizacja była znacznie głębsza niż na polskiej wsi, sytuacja nie rozwinęła się lepiej, a w pewnym sensie nawet gorzej. Żydzi zostali wykończeni

$1 \quad$ H. B rod ow s k a - K u b i c z, Z chłopskiej łąki. Wspomnienia. Łódź 1994, s. 147.

2 Wobec Żydów więcej było wolno. Z prof. A. Sułkiem rozmawia M. Sta sińs ki. „Gazeta Wyborcza" 2018, nr z 2-3 VI.

3 Ibidem.

$4 \quad$ H. Zaw a d zka, Ucieczka z getta. Warszawa 2001, s. 22.

5 A. Blady-Szwajgi e r [I. Św id ow s k a], I więcej nic nie pamiętam. Warszawa 2019, s. 183-184. 
nie przez łapanie w lesie czy amatorsko w mieście, ale zostali zgarnięci i przekazani Niemcom przez francuską policję. Chyba mało dałoby się wymienić krajów, nie tylko zresztą wśród okupowanych, gdzie w okresie wojny stosunek do Żydów byłby bez zarzutu.

To wszystko, oczywiście, nie zmienia obrazu Polski z kraju nieprzyjaznego Żydom za okupacji w kraj przyjazny. Nie na tym się zresztą autor skupia, przyjmując pewien stan rzeczy jako dany. „Najważniejszym z tych [tj. realizowanych] celów pisze - okazywało się usunięcie Żydów z Polski i przejęcie ich majątku. Współpraca $\mathrm{w}$ tym dziele przybierała wiele form, od wrogiego i izolującego przyglądania się poczynaniom nazistów, przez rabunek, do bezpośredniej agresji, wszystkie jednak miały ten sam skutek: uniemożliwiały eksterminowanym ucieczkę i w efekcie prowadziły do ich śmierci” (s. 241). Pisze, że ze względu na tę postawę „decydującej większości polskiego społeczeństwa” pomoc była niemożliwa - „nawet taka, na jaką pozwalałyby stworzone przez okupanta warunki” (s. 241). Otóż nie jestem pewien, czy takie stwierdzenie nie jest mimo wszystko nadmiernie uogólnione. Sam chętnie zniuansowałbym - poza sytuacjami jednoznacznie pozytywnymi i jednoznacznie negatywnymi - stosowanie terminów „pomoc” i „tępienie”. Już wielokrotnie zauważono, że „szmalcownicy” byli znacznie groźniejsi, niż wynikałoby to z ich liczby każdy bowiem mógł być potencjalnym „szmalcownikiem”, a więc niebezpieczni byli wszyscy poza wyjątkami. Pomoc mogła wyrażać się w całym wachlarzu zachowań mniej lub bardziej ryzykownych i mniej lub bardziej szlachetnych. Zachowałbym kategorię „obserwatorów” czy ludzi stojących z boku - nawet jeśli wiem o sytuacjach, $\mathrm{w}$ których nieudzielenie pomocy było równoznaczne $\mathrm{z}$ wyrokiem. Ludzie stojący $\mathrm{z}$ boku występuja po prostu w wypadku każdego konfliktu (chyba że obejmuje on już dosłownie wszystkich). Mocno wziąłbym pod uwagę mechanizmy psychologiczne, działające podczas konfliktów.

Dalsza sprawa: historia różnych krajów, także późniejsza, pokazała, jak łatwo właśnie sassiedzi stają się wrogami lub jak łatwo przechodzi się do niszczenia słabszych sąsiadów. Do tego nie trzeba ani Polaków, ani Żydów, niekoniecznie potrzeba nawet endecji. $Z$ dwóch grup uderzonych przez trzecią, silniejsza, jedna prawdopodobnie zaatakuje druga. Tak zadziała mechanizm przeniesienia agresji; kierunek może też wskazać zadawniona niechęć. Warto byłoby chyba przy tym wszystkim zająć się też szerzej mechanizmami długiego trwania niechęci grup etnicznych. Polska nie jest bowiem specyficzna w tym zakresie. Spotkałem kiedyś w Paryżu małżeństwo, które wyemigrowało z byłej socjalistycznej Jugosławii. Pochodzili $\mathrm{z}$ różnych tamtejszych nacji. Pozostanie wspólnie na miejscu stało się niemożliwe. Utkwili mi w pamięci, choć nawet nie zapamiętałem ich imion.

Wszystkie wymienione okoliczności warto mieć na uwadze, ale one nie zmieniają faktycznego obrazu stosunków chrześcijańsko-żydowskich pod okupacją, znacznie gorszego niż proponowany nam przez lata. Autora interesuje nie sam obraz, ale właśnie jego wersja przedstawiana. Czyści wizję zaistniałą w literaturze i filmie. No i tu pojawiają się moje opory - choć nie wątpię, że Żukowski zarysował swoje obserwacje adekwatnie do treści analizowanych dzieł. Odbieram jednak autorskie studium właśnie jako rozbiory tekstów, a nie jako analizy socjologiczno-literackie. Można, oczywiście, powiedzieć, że całość jest wypowiedzią z zakresu socjologii odwzorowy- 
wania przeszłości - skoro pokazuje zaangażowanie twórców w zdjęcie oskarżenia $z$ narodu. Tak, ale chętnie wziąłbym pod uwagę parę spraw. Po pierwsze, okoliczność, że zjawisko wzięcia pod uwagę własnych win dopiero w kolejnym pokoleniu wystąpiło powszechnie w różnych krajach. Nie przyrównując różnorodnych przewinień i nikogo nie usprawiedliwiając, gdyż w ogóle nie jestem sędzią, sugeruję przypomnienie sobie, że praktycznie wszędzie najpierw zrzucano winy na negatywnie oceniane jednostki (w Niemczech na wybrane formacje), a dopiero $\mathrm{z}$ czasem dostrzegano, że zjawiska były nie tylko jednostkowe. Znacznie później akceptowano, że społeczość jako całość lub prawie całość co najmniej nie przeciwstawiała się złym czynom, a nawet brała w nich udział. Oczywiście, że w Polsce Sasiedzi Grossa zaskoczyli opinię. Takie zaskoczenie pojawiło się jednak nie tylko w Polsce i nie tylko w wypadku Grossa. Można wskazać kilku autorow, którzy zaskoczyli opinię publiczną w różnych krajach. Ciekawe nb., że nieraz byli to cudzoziemcy - jak gdyby przełamanie standardu myślenia przychodziło im łatwiej niż historykom „tubylczym”.

Druga kwestia: brakuje mi w książce zauważenia, że realia nieraz naprawdę tłumaczyły działania. Dziś obawy, jakie powstrzymywały aliantów przed zbombardowaniem obozów koncentracyjnych, wydają się nam tragicznie absurdalne. Wtedy jeszcze nie musiały się tak rysować. Koncentrowanie się aliantów na pobiciu Hitlera dużo tłumaczyło w wielu sprawach. Mówi się, że Polska została zdradzona przez swych sojuszników. Żydzi podobnie - w imię walki $z$ Hitlerem. Sam $n b$. w obu wypadkach mówiłbym nie o społecznościach „zdradzonych”, ale raczej poświęconych, pozostawionych własnemu losowi - właśnie zgodnie z logika wojny światowej. Dostarczanie broni do getta przez AK szło marnie nie tylko $z$ uwagi na - często rzeczywistą - niechęć do Żydów, ale na różne realne przesłanki. Może rzeczywiście Władysław Bartoszewski, przywołując zdanie Marka Edelmana o tym, że getto nie spieszyło się do powstania, wybiela polskich chrześcijan - ale to był element rzeczywistej sytuacji. Posłużę się tu obserwacją sformułowaną przez mego Ojca, który podczas okupacji miał szanse niemało wiedzieć. Otóż Ojciec ex post zanotował, że powstanie w getcie mogło wybuchnąc, gdy pozostało tam już relatywnie mało ludzi, przeważnie już młodych, już bez rodzin i już wiedzących, jaka ich czeka przyszłość. Nie mogło wybuchnać, gdy skazani mieli jeszcze ojców, matki, dzieci i wciąż „wierzyli, że podłość ludzka ma przecież granice. Nie chcieli, nie mogli uwierzyć, że granic nie ma"6.

Nieraz w autorskiej analizie brakuje mi spojrzenia na rzeczywistość, w której tekst się pojawił, oraz na audytorium, do którego był skierowany. Żukowski kładzie nacisk na elementy wybielania narodu zawarte w twórczości Bartoszewskiego czy Jana Błońskiego. Mówi, że „polskie dyskusje dotyczące Zagłady uwikłane są w obronę narodowego autowizerunku" (s. 119). Myślee, że w Polsce w ogóle panuje hagiograficzny stosunek do własnych dziejów i tendencja do obrony przed wszelkimi zarzutami, nie tylko w rozważanej sprawie. Byłoby warto postawić pytanie „dlaczego?” Wróćmy jednak do tekstów Błońskiego czy Bartoszewskiego. Otóż chcę powiedzieć - tym razem jako świadek historii! - że zarówno ja sam, jak i bliskie mi osoby odbieraliśmy zarówno książkę Ten jest $z$ ojczyzny mojej, jak i esej Biedni

6 W. Kula, Rozdziatki. Do druku podali N. As sorodobraj-Kula i M. Kula. Oprac. oraz wstępem i przypisami opatrzył M. Ku la. Warszawa 1996, s. 315-316 (zapis pod datą 8 VII 1972). 
Polacy patrza na getto odmiennie, niż odczytał je autor omawianej tu pracy. Zostawmy na boku kwestię, co Władysław Bartoszewski i Zofia Lewinówna mogli w swoim czasie opublikować (choć warto mieć to pytanie w głowie). Można założyć, że książka, nawet jeśli cenzura coś skreśliła, przynajmniej z grubsza odpowiadała planowi twórców. W kontekście słów Bartoszewskiego, że wiele więcej nie dało się za okupacji zrobić dla pomocy Żydom, Żukowski zwraca uwagę:

Problem niechcianej wiedzy o polskich zachowaniach wobec Żydów w czasie wojny i po niej nie dotyczy jednak tego, czego nie sposób było zrobić i czego nie zrobiono. Wiąże się raczej z tym, czego można było nie robić, a co polskie społeczeństwo jako zbiorowość jednak uczyniło. Odpowiadające realiom uwagi o niemożliwości masowej pomocy ofiarom Shoah zakrywają wiedzę o skali i skuteczności przemocy, a więc współudziału w Zagładzie. [s. 240-241]

\section{Według autora, wbrew znanym sobie negatywnym faktom -}

[Bartoszewski] tak buduje wypowiedź, żeby oddzielić niebezpieczeństwa grożące ratującym ze strony polskiego otoczenia od obrazu narodu i zatrzeć przy tym skalę problemu. Denuncjacje okazuja się wyjątkiem na tle reguły pomocy, jednocześnie są dziełem osób działających z niskich pobudek, a więc ludzi, których nie sposób zaliczyć do narodowej wspólnoty. [s. 213]

Może autor ma rację. Może rzeczywiście Bartoszewski tak przedstawiał sprawę, realizując swoistą pedagogikę (byliście dobrzy, a bądźcie lepsi) czy też dlatego, że zapewne widział naród jako umęczony przez komunizm i chciał - mniejsza o to, czy świadomie - jego jednoczenia, przywracania mu wiary w zbiorowe ,ja”, optymizmu. Warto jednak pamiętać, że zbiór pod redakcją Bartoszewskiego i Lewinówny ukazał się w czasie wzrostu nacjonalistycznej, moczarowskiej fali. Te teksty poświadczały bliskość Polaków i Żydów (niech już będzie to potocznie używane określenie, dzielące społeczeństwo). Przeciwstawiały się mówieniu, że Żydzi to w najlepszym wypadku goście.

Podobnie, znacznie później, nie odbieraliśmy tekstu Błońskiego jako wybielania narodu, lecz jako zganienie szerokiej obojętności względem losu Żydów. Także w ten sposób interpretowaliśmy film Pawła Łozińskiego. Zgoda, pokazanie w nim ekshumacji szczątków Abrahama Grynberga „nie prowadzi do niczego poza oburzeniem na sprawców, którzy zawsze okazują się figurą nie-ja. Kwestia grupowego współudziału w zbrodni czy zbiorowej woli pozbycia się Żydow w tym horyzoncie nie może się pojawić. Rozmywają się pytania o stosunek polskiej społeczności do ofiar, działania wobec nich, wreszcie o korzyści, których dopatrywano się w eksterminacji. Opowieść o Zagładzie jest formą obrony przed tego rodzaju pytaniami i wiedzą, która niosą wywołane z pamięci obrazy" (s. 70). Muszę jednak postawić kwestię: czy Łoziński eliminuje niewygodne pytania w ramach budowania dobrego samopoczucia społeczności widzów, czy raczej właśnie pokazuje jej dotychczasowy brak chęci spojrzenia na ważny fragment swojej przeszłości? Może istotne było pokazanie, że ofiara mogła być zabita nie przez Niemców, lecz jak najbardziej przez miejscowych? Może warto pamiętać, że nie tak wielu wówczas mówiło o takiej możliwości, a dla znacznej części widzów stanowiło to $z$ pewnością zaskoczenie. Ktoś pokazał w polskim filmie, że na polskiej wsi Polacy zamordowali Żyda...

Oczywiście, jako świadek historii mówię z pamięci. Może upiększyłem swój odbiór tych oraz innych dzieł analizowanych przez autora. Wiem, że książki takie, jak 
Bartoszewskiego i Lewinówny, były moczarowcom wygodne. Nie mam watpliwości, że - co zauważa Żukowski - hołdy wobec Sprawiedliwych bywają instrumentalne. Pamiętam ministerialne programy nauczania historii w szkołach za PRL - niektóre miałem okazję przeczytać - gdzie los polskich Żydów był „załatwiony” punktem o okazywaniu pomocy przez Polaków. Komuniści, wbrew dzisiejszej potocznej opinii, w wielu sprawach nie chcieli drażnić opinii ludzi, nieraz chcieli się im wręcz przypodobać (Moczar, Gierek). Komunizm się skończył, a przekonanie o chwale narodu w pomocy Żydom - pozostało. Doszło natomiast lub dało się słyszeć oskarżanie Żydów o (rozdymany) udział w niecnych czynach, takich jak witanie Armii Czerwonej czy działanie w UB - o czym np. w wypadku „Ognia” chętnie się zapomina.

Przekonanie o masowo udzielanej pomocy jest wzmacniane przez różne ośrodki kształtowania opinii. Sam premier Mateusz Morawiecki przywoływał jakieś gigantyczne liczby pomagających, zadeklarował, że Polska jako kraj powinna mieć drzewko w Instytucie Jad wa-Szem itd. Wszystko to jest elementem nastawienia się na rozwijanie dumy $z$ własnej historii na dowolnym polu - doprowadzonego do takich rozmiarów, że świadczy ono albo o kompleksach niższości, albo o niespełnionych marzeniach o wielkości, albo o jednym i drugim razem - jednako nie wiem, z czego wynikające, ale ciekawe jako zjawisko. Zakompleksionym jest trudniej, oczywiście, przyjąć negatywne opinie o sobie niż pewnym siebie.

Mimo to wszystko zdanie Żukowskiego: „Z hołdów wobec Sprawiedliwych nie wynika włączenie Żydów do polskiej wspólnoty” (s. 188), wydaje mi się niepełne. Oczywiście, bardzo szeroko panuje w Polsce przekonanie, że Żydzi to Żydzi, a Polacy to Polacy. W Muzeum Emigracji w Gdyni, przynajmniej parę lat temu, niedługo po otwarciu, gdy je zwiedzałem, emigracja Żydów z Polski po wojnie została skwitowana zdaniem o wyjeździe do ojczyzny (cytuję z pamięci!). O pogromie kieleckim i paru innych sprawach tam zapomniano. Zresztą była to przecież emigracja mniejszości... Oczywiście, można zapytać, dlaczego w Polsce myślenie w kategoriach narodu przeważa nad myśleniem $\mathrm{w}$ kategoriach obywatelstwa. To zreszta widać choćby w samym stosowaniu terminów „Polacy” i „Żydzi” - co zakłada pominięcie obywatelstwa. Znowu trzeba dodać, że Polska nie jest wyjątkiem w tym zakresie. Nawet Stany Zjednoczone internowały podczas wojny własnych obywateli Nippo-Amerykanów - a trwanie konfliktu zbrojnego mało zmienia $z$ rozważanego punktu widzenia. W Izraelu też „etniczność” często traktuje się jako istotniejszą od autoidentyfikacji, identyfikacji kulturowej, miejsca życia itd. Zostawmy jednak kwestię, dlaczego tak się dzieje. Nie wątpię, podobnie jak autor, że wiele polskich ceremonii honorowania Sprawiedliwych ma akcent podkreślania, że naród polski jest dobry, że było tylu ratujących... Zgadzam się z polemiką Jana Grabowskiego $\mathrm{z}$ premierem Morawieckim, że powinien on wiedzieć, iż, powiedzmy, w powiecie węgrowskim, zamieszkiwali i działali nie tylko wspominani przez niego Polacy, którym należy się hołd, ale „w miastach i miasteczkach tego powiatu doszło do krwawych polowań na Żydów, w których oprócz Niemców wzięli udział polscy strażnicy, policjanci oraz zwykli mieszkańcy"7. Premier powinien - pisał Grabowski - poznać świadectwo Adama Starkopfa, który, ukrywając się w Sadownem,

7 J. Grabow s ki, Czego trzeba, by Dzień Pamięci Polaków Ratujacych Żydów nie stat się farsa. „Gazeta Wyborcza” 2019, nr z 28 III. 
zasłyszał miejscowych, mówiących: „Lećmy ich brać, później odda się ich na gestapo. Bierzemy ich ubrania, wszystko, co mają w kieszeniach, a na koniec Niemcy nam zapłaca za doprowadzonych Żydów!"8. Bohaterstwo w ratowaniu łatwo mogło sąsiadować $z$ łajdactwem. Sam jednak nie powiedziałbym w odniesieniu do ceremonii honorowania Sprawiedliwych, że odzwierciedlają one „zestaw fobii i uprzedzeń, o których wszyscy wiedzą, ale o których nikt nie chce mówić, zasłaniając się koniecznością przypominania o "pozytywnych stronach" polsko-żydowskiej historii" (s. 188). Sam nie uogólniałbym aż tak. Może mam za mało zacięcia prokuratora, który tropi znaki pomniejszania zbrodni własnej grupy i demaskuje winnych. Hołdy oddawane Sprawiedliwym zawierają w sobie wszakże różne aspekty, dla jednych takie, dla drugich inne. Nawet chęć, by naród starał się przedstawiać w dobrym świetle, sama w sobie nie jest przecież naganna. Pytanie tylko, czy podejście takie nie staje się jednostronne i czy nie zaciera negatywów. Nie można jednak łączyć ze sobą Bartoszewskiego, kładącego nacisk na działania Sprawiedliwych, i Gontarza z marca 1968, który też lubił ten wątek. Nie twierdzę, że autor to robi, ale... warto zachować ostrożność, by tok rozumowania nie prowadził na taką drogę. Nie po to, żeby wytaczać kolejny argument w dyskusji, a jedynie dla przytoczenia barwnego obrazka, na którego przechowaniu mi zależy, przytoczę wspomnienie $z$ okresu przed wyborami z 1991 roku. Na plakatach różnych kandydatów pojawiały się wtedy antysemickie dopiski. Bartoszewski i Bronisław Geremek jechali razem samochodem przez Polskę. Przy jakimś dopisku na plakacie Geremka Bartoszewski się żachnął. Geremek machnął ręką, w sensie: „Mniejsza o to, mnie to nie przeszkadza”. Na to Bartoszewski wybuchną: „Ale mnie to przeszkadza!” (cyt. z pamięci).

Kolejna - ostatnia, ale istotna sprawa. Nie ja, historyk, będę mówił autorowi, że każdy utwór jest uwarunkowany swoimi czasami. Cenne jest zwrócenie przezeń uwagi na rzadko przedtem dostrzeganą, negatywną cechę tekstów, których twórcy mieli nawet jak najlepsze intencje. To realizacja zalecenia uniwersalnego. Mówiąc o zakonnikach w Ameryce dziś zwanej Łacińską - co mnie kiedyś interesowało trzeba pamiętać, że jakkolwiek często bronili Indian, nie widzieli niczego złego w wykorzystywaniu Murzynów jako niewolnikow (chrzcili ich en masse, a potem...). Myśląc o Marcinie Lutrze, trzeba pamiętać, że źle pisał o Żydach - choć był wielkim reformatorem otaczającego świata. Brutalnie powiem jednak (przepraszam autora!), że wytykanie takich negatywów $\mathrm{z}$ całą mocą brzmi trochę tak, jak poprzedzanie spektaklu Wesela dla robotników wstępem, że Stanisław Wyspiański jeszcze nie rozumiał mechanizmów życia społecznego (1954) ${ }^{9}$.

Analizowani w recenzowanej książce autorzy niekiedy faktycznie chcieli zafałszować historię w tym sensie, że zależało im wyłącznie na daniu dobrej cenzurki własnemu narodowi, ale niekiedy - mając jak najlepsze intencje - mówili tak, jak „się mówiło”. Każdy z nas jest uwarunkowany sposobem myślenia dominującym w czasach, w których żyje. Pytanie, w jakim stopniu i kierunku udaje się nam od tego sposobu oddalić. Najczęściej trudno zrobić to radykalnie. $Z$ dzisiejszego punktu widzenia Marsylianka jest po prostu okropna (wrogów „nieczysta krew”!). Murzynek Bambo może dziś wzbudzać nasze zastrzeżenia. Wykrycie, że jego autor był

Ibidem.

J. Krakow s ka, Mikołajska. Teatr i PRL. Warszawa 2011, s. 172. 
pod wpływem stereotypów antymurzyńskich, nie mijałoby się z prawda. $Z$ pewnością warto sobie z tego zdawać sprawę. Sam jednak - pewno jako historyk - pamiętałbym też, że ów wiersz został napisany z dobrą intencją, a także to, jak go w tamtym momencie odbierano, i to, że jego rola była pozytywna na ogólnym tle. Ten Bambo to był przecież „nasz koleżka”! Z punktu widzenia dzisiejszych historyków obraz przedstawiony niegdyś w Chacie wuja Toma Harriet Beecher Stowe ma dużo ułomności. Niemniej jednak chyba trudno go ganić, nieprawdaż? Fundamentalna dla współczesnej kultury brazylijskiej książka, znana w Polsce pod nie najlepiej oddanym tytułem Panowie i niewolnicy Gilberta Freyre’a, jest dziś z różnych powodów krytykowana. Przecież jednak swego czasu to w niej został zarysowany akceptowany współcześnie obraz cywilizacji stworzonej przez trzy grupy etniczne, nie tylko przez Białych. $Z$ bliższego nam pola: niedawno czytałem przygotowane do druku przez Kornelię Kończal i Joannę Wawrzyniak listy prof. Stefana Czarnowskiego. Doprawdy, był to obrońca Żydów na Uniwersytecie Warszawskim w Dwudziestoleciu (mogę to rozwijać!). Tymczasem niektórych sposobów jego rozumowania w tej sprawie, widocznych w korespondencji, dziś bym nie zaakceptował.

Warto sobie zdawać sprawę zarówno z dobrych intencji Tuwima czy wielu innych twórców, jak i z tego, że nie wyzwolili się oni z pewnej konwencji, niekiedy nieadekwatnej do rzeczywistości, czasem nawet krzywdzacej dla zainteresowanych. Po pierwsze, jedno i drugie jest ciekawe oraz istotne. Po drugie zaś, gdyby rozpatrywać dzieła literackie, historyczne i wszelkie tylko według kryteriów dzisiejszych, to sporą część światowego dorobku należałoby wyrzucić. Jesteśmy od tego, żeby właśnie pokazywać, co w dziele było częścią czasów autora, w czym on nie nadążał, w czym się im sprzeciwiał, a w czym je wyprzedził - na dobre lub na złe. Cieszę się, że autor przedstawił mi tę stronę sprawy, którą dotychczas sam - przyznaję - mało dostrzegałem.

\section{Abstract}

MARCIN KULA The Aleksander Zelwerowicz National Academy of Dramatic Art, Warsaw ORCID: 0000-0002-2539-6895

\section{WHAT ABOUT BAMBO THE LITTLE NEGRO?}

The reviewer discusses Tomasz Żukowski's approach to presenting the newest relationships between the Polish Christians and the Polish Jews. The discussion is led on the margin of Żukowski's book Wielki retusz. Jak zapomnieliśmy, że Polacy zabijali Żydów (A Great Retouch. How We Have Forgotten That Poles Killed Jews). The reviewer admires the book, and at the same time criticises its theses as unidirectional. 